\title{
How do we assess the quality of corporate financial reporting? A methodological issue
}

\author{
Hasan, Md. Shamimul \\ Omar, Normah \\ - ReCeIVED: 26 JuNe 2015 \\ - AcCePTED: 22 SEPTEMBER 2015
}

\begin{abstract}
The purpose of this study is to show a new way of assessing the quality of corporate financial reporting. We assess the quality of corporate financial reporting in Bangladesh, a country where the family predominates and the business environment is virtually unregulated, with managerial incentives rather than regulatory influence more likely to induce disclosures and to influence other reporting issues. Both quantitative and qualitative measures are taken into consideration to account for various aspects of financial reporting, as a single proxy does not cover multiple aspects. The overall disclosure index (proxy 1 ) and corporate accruals (proxy 2) are taken as quantitative measures, while external users' perceptions about financial reporting (proxy 3 ) are taken as a qualitative measure. Lower disclosure index values, higher corporate accruals, and users' negative impressions result from lower quality financial reports. This study provides a new way of measuring the quality of financial reporting and contributes two new proxies (proxy 1 and proxy 3 ) to the existing literature on assessing the quality of financial reporting.
\end{abstract}

\section{Keywords:}

Financial reporting quality, corporate accruals, disclosure index, external users' perception, Bangladesh, discretionary accruals, earnings management.

\section{JEL classification:}

M41.

Dr. Hasan, M.S. Post Doctoral Scholar, Accounting Research Institute (ARI), Universiti Teknologi Mara (UiTM), Shah Alam, Selangor, Malaysia. E-mail: dr.mdshamimulhasan@rocketmail.com

Dr. Omar, N. Professor and Director,Accounting Research Institute (ARI), Universiti Teknologi Mara (UiTM), Shah Alam, Selangor, Malaysia. E-mail:normah645@salam.uitm.edu.my 


\title{
Cómo evaluar la calidad de la información financiera corporativa. Una cuestión metodológica
}

\author{
Hasan, Md. Shamimul \\ Omar, Normah
}

\section{Resumen}

El propósito de este estudio es mostrar una nueva manera de evaluación de la calidad de la información financiera corporativa. Se evalúa la calidad de dicha información en Bangladesh, un país con claro predominio familiar, con, prácticamente, un entorno no regulado en el que son los incentivos de gestión, más que la influencia regulatoria, los que generan más propensión a la divulgación y otras cuestiones relacionadas con la información. Se consideran tanto medidas cuantitativas como cualitativas para dar cabida a distintos aspectos de la información financiera, ya que una única variable proxy no cumple con dicha función. Las variables cuantitativas son el índice global de divulgación de la información (proxy 1 ) y los devengos (corporativos, proxy 2), mientras que como variable cualitativa se utilizan las percepciones de los usuarios externos de la información financiera (proxy 3). La consecuencia de una menor calidad en los informes financieros se traduce en un menor índice de divulgación de la información, mayores devengos "corporativos" y una impresión negativa por parte de los usuarios. Este artículo proporciona una nueva manera de medir la calidad de la información financiera y aporta dos nuevas variables proxy (proxy 1 y proxy 3 ) a la literatura existente sobre la cuestión.

\section{Palabras clave:}

Calidad de la información financiera, devengos "corporativos", índice de divulgación, precepción de los usuarios externos, Bangladesh, devengos discrecionales, gestión de ingresos. 


\section{Introduction}

The recent capital market crash (2011) in Bangladesh, a country where the family predominates, has created doubt in stakeholders' minds about the quality of the present financial reporting system, auditor integrity, veracity of corporate management, service quality of regulators, and the failure of the legal system to protect the rights of shareholders. The stock market investigation committee (2011) found a great deal of malpractice at firm level, market level as well as regulator level. Accounting manipulation such as overvaluation of assets, earnings manipulation, lack of provision for deferred tax on revaluation, bonus issue from unrealized gains, false reporting, and so on, occurred at firm level. At market level, price manipulation in placement, book building, direct listing, bonus issue, right issue, serial trading, advance declaration, and rumors, were revealed, among other things. Since regulators themselves were involved in unethical activities, the committee recommended the removal of top executives from the Securities and Exchange Commission. Furthermore, a number of valuers, issuers, issue companies, and auditors were involved in the manipulation process. The probe committee reveals a snapshot of corporate behavior in Bangladesh, whereby the auditors do not carry out their duties properly and would seem to be working for the chair of the companies instead of protecting shareholder rights.

Current corporate governance practice also leaves much to be desired: boards are not truly independent; most of the ownership of companies is in the hands of family members; institutional roles are very limited; few financial statements are audited by reputable audit firms; there is no professionalism in the boardroom; market regulators and operators are weak; and chairmen and CEOs are politically well connected, all of which could be considered as causes of a poor corporate reporting environment (Hasan et al., 2014a).

Corporate financial reporting is a virtually unregulated environment where managerial incentives rather than regulatory influence are more likely to induce disclosures and to influence other reporting issues. A number of factors including the ambiguous role of regulators, the high volatility of capital markets, users' limited accounting knowledge, an unhealthy national political culture and legal system, poor enforcement of law and order and unethical practices of some vested quarters, poor corporate governance mechanisms, and lack of a decentralized authority all help to create a poor reporting environment in Bangladesh. It is worth noting that the quality of financial reporting is not comparable to other developing countries let alone developed countries. Moreover, the behavior of variables in a developing economy is not the same as in a developed economy. 
Publicly listed companies disclose information in annual reports for many reasons. It may be due to rules and regulation, to the needs of 'user groups', or to the willingness of the management of the company. This information is very important to external stakeholders as they use annual reports to analyze corporate operating performance at the end of each financial year. When making their investment evaluation, they therefore have a pressing need for quality information to measure the true performance of corporate management. The Financial Accounting Standard Board (FASB) and the International Accounting Standard Board (IASB) also emphasize the quality of financial reports but to date they have not provided a universally accepted method of measuring the quality. Therefore, researchers use arbitrary techniques in evaluation the quality of corporate financial reports. Accrual models, value relevance models, research focusing on specific elements, qualitative characteristics such as readability, objectivity, predictive value, neutrality, representational faithfulness, feedback value, timeliness, and so on, are generally used in assessment procedures. Researchers usually apply at least two measurement methods, as a single proxy is unlikely to cover all aspects of financial reports. In this study, we use overall disclosure index and corporate accruals as quantitative measures and users' perceptions about financial reporting as qualitative measures.

The proxies overall disclosure index and users' perceptions about financial reporting represent new contributions to the literature. We argue that the disclosure index is an important measure of the extent of disclosure. Companies demonstrating higher levels of disclosure are held in higher regard than those showing lower levels of disclosure. On the other hand, corporate financial reports are prepared for the external users and hence users' perceptions about financial reports are also important. Positive perceptions indicate high quality while negative perceptions indicate lower quality of financial reports. Therefore, these two important proxies are taken into consideration to fill the methodological gap relating to the assessment of financial reporting quality. Moreover, the issue of the quality of financial reports within the context of Bangladesh's current precarious situation urgently needs to be addressed. To date, there has been no assessment of the quality of financial reports in Bangladesh. We take this opportunity to fill this gap in the literature. The objective of this study is to introduce a new way of assessing the quality of corporate financial reports. The specific contribution of this study lies in the introduction of two new proxies to the procedure for assessing corporate financial reporting quality; these two proxies are a disclosure index and users' perception of financial reports. In addition, this study also explores the quality of financial reports of listed companies in Bangladesh.

This paper is organized as follows. The next section presents a literature review, followed by a focus on the research framework in section 3 , the research approach in section 4, results and discussion in section 5 , and conclusions in section 6 . 


\section{Literature review}

The improvement of market efficiency depends on high quality information disclosed in financial statements that can help stakeholders when making investment, credit, and resource allocation decisions ${ }^{1}$. Although the FASB and the IASB emphasize the importance of high-quality financial reporting, one of the key problems is how to measure quality (Beest et al., 2009). The evaluation of the quality of financial reporting obviously requires choices to be made between determining elements, since financial reports are context-specific (Dechow and Dichev, 2002; Schipper and Vincent, 2003; Botosan, 2004; Daske and Gebhardt, 2006). Perceived quality of financial reporting differs among constituents as different user groups have different preferences. In addition, even within a user group different users may perceive the usefulness of information in different ways given its context. Thus, measuring quality of financial reporting is made difficult due to context and user-specificity (Botosan, 2004). The measurement of the quality of financial reporting depends on attributes affecting the quality of financial reports, such as earnings management, financial restatements, and timeliness (Barth et al., 2008; Schipper and Vincent, 2003; Cohen et al., 2004). There is no universally approved single measure of financial reporting quality (Dechow et al., 2009). The various tools and techniques for measuring different attributes that are believed to influence financial reporting quality are used to assess the overall quality of financial reports. Beest et al. (2009) provides a non-exhaustive classification of methods most widely used in prior literature to assess financial reporting quality, i.e., accrual models, value relevance models, specific elements in the annual report, and methods that operationalize the qualitative characteristics.

Accrual models and value relevance only focus on information disclosed in financial statements to assess financial reporting quality (Healy and Wahlen, 1999; Dechow et al., 1995; Barth et al., 2001; Choi et al., 1997; Nichols and Wahlen, 2004; Leuz, 2003). The quality of earnings is directly related to the quality of discretionary accruals (accruals as chosen by managers). Higher discretionary accruals suggest lower quality earnings, while lower discretionary accruals suggest higher quality earnings. That is why the quality of financial reporting depends to a large extent on discretionary accruals. Context-specific research papers are not able to assess financial reporting quality (Hirst et al., 2004; Gearemynck and Willekens, 2003; Beretta and Bozzolan, 2004; Cohen et al., 2004). A single proxy is unlikely to cover all aspects of financial reporting quality (Chen et al., 2011) and so most researchers use more than one method to measure the quality of financial reporting (Tang, 2008; Biddle et al., 2009; Beest et al., 2009; Chen et al., 2011). Tang (2008) developed quality indicators relating

${ }^{1}$ IASB (2008). Exposure draft on an improved conceptual framework for financial reporting:The objective of financial reporting and qualitative characteristics of decision-useful financial reporting information. London. 
to five aspects of financial reporting: loss avoidance ratio, profit decline avoidance ratio, accruals ratio, qualified audit opinion ratio, and non-Big 4 auditor ratio. $\mathrm{He}$ then constructed a quality index based on these indicators. Biddle et al. (2009) used three proxies to measure the quality of financial reporting, including a measure of accruals quality derived by Dechow and Dichev (2002), a measure of accruals quality proposed by Leuz et al. (2008) and a measure of readability of financial statements proposed by Li (2008) called the FOG Index. Beest et al. (2009) measured the quality of financial reporting in terms of qualitative characteristics. They developed a quality assessment tool using a 21 -item index comprising both fundamental (relevance and faithful representation) and enhancing qualitative characteristics (understandability, comparability, and timeliness). A five-point rating scale was used to compute a standardized score for the fundamental and enhancing qualitative characteristics. The standardized score for the fundamental qualitative characteristics 'relevance and faithful representation' was calculated by adding the standardized scores of relevance and faithful representation and then dividing it by 2 . The same procedure was performed for enhancing qualitative characteristics, resulting in a score between 1 and 5 for all qualitative characteristics, with 1 representing a poor score and 5 indicating an excellent score. The quality of financial reporting was measured by including scores for both the fundamental and enhancing qualitative characteristics. Chen et al. (2011) used three measures that have been used in prior research as well as an aggregate measure in order to assess the quality of financial reporting: the first measure was performance-adjusted corporate accruals as developed by Kothari et al. (2005); the second proxy was estimated corporate revenues as used by McNichols and Stubben (2008) and Stubben (2010); and the third proxy was based on the cross-sectional Dechow-Dichev (2002) model, as modified by McNichols (2002) and Francis et al. (2005). Finally, to alleviate measurement error in the individual financial reporting quality (FRQ) components, and to provide evidence based on an overall FRQ metric, they aggregated the three proxies into one aggregate score. Specifically, following Biddle et al. (2009) they first normalized all proxies and then took the average of the three measures as a summary FRQ statistic (Aggreg).

However, while assessing financial reporting quality, the above-mentioned researchers did not focus on the comprehensiveness of disclosures published in the annual report nor external users' perceptions about financial reporting. Measuring the level of disclosures (financial and non-financial) is an important aspect in assessing financial reporting quality. CFA Institutes ${ }^{2}$ defined high financial reporting quality as overall financial reporting including disclosures, which results in a fair representation of a company's operations (including both earnings and cash flows) and financial position. Financial disclosures are significantly linked to corporate governance (Hasan et

${ }^{2}$ CFA Institute. (2012). Financial Reporting and Analysis. Pearson. USA 
al., 2013a); likewise, corporate attributes are significantly linked to disclosure index (Hasan et al., 2013b). Since external users are the main beneficiary of financial reports, their perceptions about corporate financial reports is another important aspect. Their perceptions (whether negative or positive) about financial reports can be a way of assessing the quality of financial reports. We argue that negative perceptions indicate lower quality and positive perceptions indicate higher quality of financial reports. In addition, the quality of financial reporting has not yet been studied in context of Bangladesh; we thus strive to bridge these gaps (study gap and methodological gap) and we believe that this study contributes to the existing literature on the assessment of the quality of corporate financial reports.

\section{Research framework}

The following research framework is designed to show a graphical representation of the diagnostic pattern of the problem under study. In this diagram, we show three proxies of financial statement analysis. The disclosure of financial reports is shown under proxy 1 , earnings management or corporate accruals is shown under proxy 2 , and users' perception about financial statements is shown under proxy 3 . We then evaluate the results of these three proxies to assess the quality of corporate financial reporting. Lower levels of disclosures, higher levels of corporate accruals and users' negative perceptions are the result of lower quality financial reports, whereas higher levels of disclosures, lower levels of corporate accruals and users' positive impressions are the result of higher quality financial reports. The diagram of the research framework is shown in Figure 1.

\section{Figure 1. Research framework for the quality of corporate financial reporting}

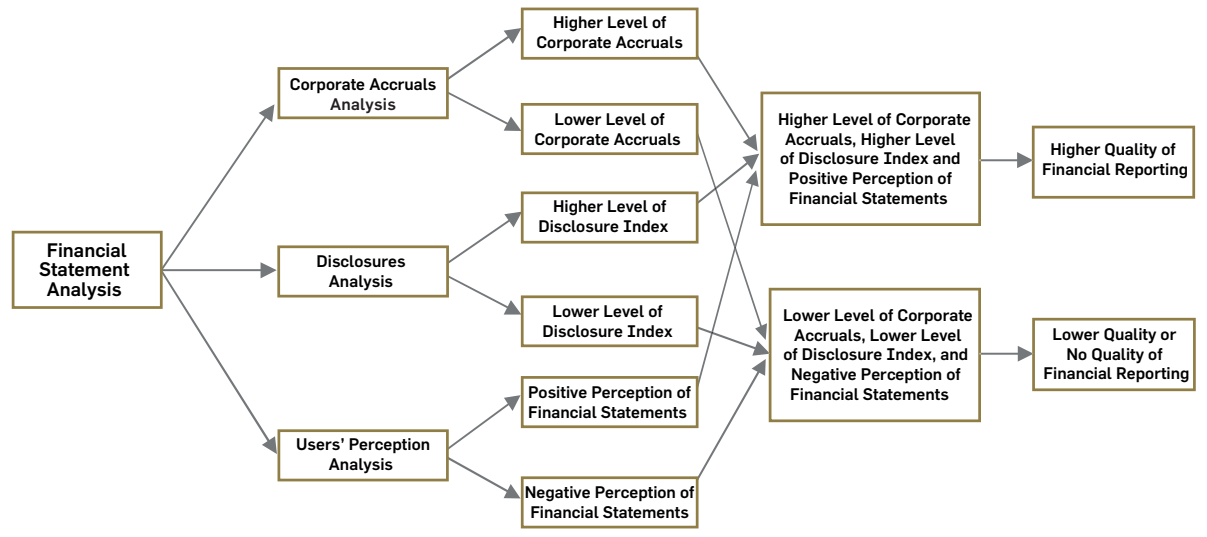




\section{Research approach}

For Proxy 1 (overall disclosure index), we analyze the results of our previous study on disclosure in Bangladesh, where annual reports were divided into eight segments (Hasan et al., 2012a, 2012b). They are general disclosure items (GD), company profile disclosure items $(C P)$, director's report items $(D R)$, financial highlight items $(F H)$, accounting policies items $(A P)$, income statement items $(I S)$, balance sheet items $(B S)$ and cash flow statement items (CFS). A total of 200 disclosure items were established according to the above-mentioned categories and were reviewed in the annual report. The disclosure score is determined by using a dichotomous approach, i.e., a company is awarded 1 point if it disclosed one such item, and 0 if it did not. The Partial-Compliance Unweighted Approach was applied for measuring the overall disclosure index (ODI). In an unweighted approach, every item of disclosure is considered equally important to shareholders. According to this approach, the disclosure score is calculated first and then the ODI is calculated based on the disclosure score. The formula is as follows:

$$
P C_{j}=\frac{\sum_{i=1}^{n} X_{i}}{R_{j}}
$$

where, $P C_{j}=$ Total disclosure score for each company and $0 \leq P C_{j} \leq 1$.

$X_{i}=$ Level of disclosure for each item of disclosure.

$R_{j} \quad=$ Total number of disclosure items for each company $j$.

For proxy 2 (corporate accruals), we analyze the results of our previous study on accruals (Hasan et al., 2014b, 2014c, 2015). Corporate accruals is defined as the difference between financial statements accruals (FSA) and estimated accruals (EA). Financial statements accruals is defined in this study as the difference between net income (NI) and cash flow from operating activities (CFO) divided by lag total assets (LTA), as shown in the following equation:

$$
\left[\frac{F S A}{L T A}\right]=\left[\frac{N I}{L T A}\right]-\left[\frac{C F O}{L T A}\right]
$$

Estimated accruals is measured using a regression model (Modified Kothari-Jones Model, 2005); this model is used here in order to adjust for the performance of the organizations in the model. We then focus on the difference between the two accruals. The greater the difference, the lower the quality, while a smaller difference indicates a higher quality of corporate financial reports. The model for estimated accruals is as follows:

$$
\left[\frac{E A}{L T A}\right]=\beta_{1}\left[\frac{1}{L T A}\right]+\beta_{2}\left[\frac{\Delta R E V-\Delta A R}{L T A}\right]+\beta_{3}\left[\frac{P P E}{L T A}\right]+\beta_{4}\left[R O A_{t-1}\right]+\varepsilon
$$


where

$E A \quad=$ Estimated Accruals

$\triangle R E V=$ Change in Revenues from the preceding year

$\triangle A R=$ Change in Accounts Receivable from the preceding year

$P P E \quad=$ Gross Value of Property, Plant \& Equipment

$R O A_{t-1}=$ Lagged Rate of Return on Assets

LTA = Lagged Total Assets ${ }^{3}$.

The equation of corporate accruals is as follows:

$$
\left[\frac{C A}{L T A}\right]=\left[\frac{F S A}{L T A}\right]-\left[\frac{E A}{L T A}\right]
$$

For proxy 3 (users' perception), we analyze external users' opinions about various aspects of corporate financial reporting (Hasan et al., 2012b; Hasan, 2012a, Hasan et al., 2014b). In order to ensure homogeneity, the respondents are classified into five groups according to their occupations. A total of 190 respondents from five groups (40 bankers, 40 shareholders, 40 stockbrokers, 40 academics, and 30 tax officers) completed a structured questionnaire. Information regarding the distribution of respondents, responses, rejection, and valid responses is presented in Table 1.

Table 1. Distribution of the respondents, responses, and valid responses

\begin{tabular}{|c|c|c|c|c|c|c|c|}
\hline \multirow{2}{*}{$\begin{array}{l}\text { Respondent } \\
\text { Groups }\end{array}$} & \multirow{2}{*}{$\begin{array}{l}\text { Sample } \\
\text { Size }\end{array}$} & \multicolumn{2}{|c|}{ Responses } & \multicolumn{2}{|c|}{ Responses Rejected } & \multirow{2}{*}{$\begin{array}{c}\text { Valid } \\
\text { Responses }\end{array}$} & \multirow{2}{*}{$\begin{array}{c}\text { Percent } \\
\text { of Total Valid } \\
\text { Responses }\end{array}$} \\
\hline & & Number & Percent & Number & Percent & & \\
\hline Bankers & 60 & 45 & 75 & 5 & 11 & 40 & 21 \\
\hline Shareholders & 65 & 55 & 85 & 15 & 27 & 40 & 21 \\
\hline Stockbrokers & 45 & 45 & 100 & 5 & 11 & 40 & 21 \\
\hline Academics & 55 & 40 & 73 & & 0 & 40 & 21 \\
\hline Tax Officers & 55 & 35 & 64 & 5 & 14 & 30 & 16 \\
\hline Total & 280 & 220 & 79 & 30 & 64 & 190 & 100 \\
\hline
\end{tabular}

SOURCE:THE PAKISTAN ACCOUNTANT, 50(I), P. 26.

We analyze the results of six questions in order to examine the level of corporate financial reporting quality. These six questions address the effectiveness of existing corporate financial reporting, perceived timeliness of accounting information, adequacy of accounting information, reliability of accounting information, neutrality of accounting information, and auditor integrity. The effectiveness of existing corporate financial reporting, perceived timeliness, neutrality, and auditor integrity are measured

\footnotetext{
${ }^{3}$ All variables are deflated by lagged total assets (LTA, the total assets of the previous year) in order to reduce heteroskedasticity.
} 
on a five-point Likert scale and an F-test is used to ascertain the significance of users' opinions. Adequacy and reliability are measured on a three-point scale: fully, partly and not at all. In this case, a chi-square test is used to determine the significance of users' opinions.

Taking the aggregate results of the three proxies, we then assess the quality of corporate financial reports accordingly. If the results show higher disclosures, lower accruals and positive user impressions, then the corporate financial report is considered to be high quality; if the opposite is true then the quality is deemed to be low or non-existent.

\section{Results and discussion}

If we look at proxy 1 for the disclosure index, Table 2 shows that the overall disclosure index is 67 percent while the disclosure index for general disclosure, company profile, director's report, financial highlights, accounting policies, income statement, balance sheet, and cash flow statement are 79, 68, 71, 52, 63, 81, 67, and 55 percent respectively. The overall disclosure index and the individual disclosure index are not an adequate way of measuring corporate performance. High quality financial reporting refers to overall financial reporting including disclosures, which results in a fair representation of a company's operations (including both earnings and cash flows) and financial position. Besides, the investigation committee $e^{4}$ found major accounting malpractices among listed companies. Both quality and quantity of disclosure play a role in financial reporting quality. The level of disclosures index indicates that the financial reports are of poor quality since they do not meet the external shareholders' need for accounting information.

\section{Table 2. Descriptive statistics for the disclosure index}

\begin{tabular}{llcccccc}
\hline SN & Disclosure Components & $\begin{array}{c}\text { Maximum } \\
\text { Index }\end{array}$ & $\begin{array}{c}\text { Minimum } \\
\text { Index }\end{array}$ & ODI & SD & CV & Rank \\
\hline 1 & General Disclosure Items & 0.9 & 0.7 & 0.79 & 0.14 & 0.18 & 1 \\
\hline 2 & Company Profile Items & 1 & 0.4 & 0.68 & 0.15 & 0.22 & 4 \\
\hline 3 & Director's Report Items & 1 & 0.39 & 0.71 & 0.18 & 0.25 & 6 \\
\hline 4 & Financial Highlight Items & 0.81 & 0.23 & 0.52 & 0.19 & 0.37 & 7 \\
\hline 5 & Accounting Policies Items & 0.88 & 0.19 & 0.63 & 0.15 & 0.23 & 5 \\
\hline 6 & Income Statement Items & 0.93 & 0.64 & 0.81 & 0.15 & 0.19 & 2 \\
\hline 7 & Balance Sheet Items & 0.76 & 0.3 & 0.67 & 0.12 & 0.18 & 1 \\
\hline 8 & Cash Flow Statement Items & 0.79 & 0.4 & 0.55 & 0.11 & 0.2 & 3 \\
\hline
\end{tabular}

SOURCE: ICAN JOURNAL OF ACCOUNTING AND FINANCE, I (4), P. 63

\footnotetext{
${ }^{4}$ Investigation Committee. (20I I). Capital Market Investigation Report - 20I I. Ministry of Finance, Government of Bangladesh.
} 
Turning to proxy 2 for corporate accruals, Table 3 shows that the average rate of corporate accruals was $35 \%$. The use of discretionary accruals naturally affects the quality of financial reporting. Higher discretionary accruals indicate lower earnings quality and vice-versa ${ }^{5}$. The accrual method of accounting is considered the best technique because it allows adjustments for the accounting period. It is also a better measure of the operating performance of a business entity but it always depends on the quality of accruals. Accrual earnings are divided into corporate accruals and non-corporate accruals. Corporate accruals reduce the quality of accruals and ultimately the quality of financial reporting. External users are always anxious to receive quality financial reporting because they do not have access to company accounts or other sources of information. Stakeholder theory holds that companies always try to meet the expectations of their stakeholders, and accordingly, companies should provide reliable financial statements that can inform stakeholders' economic decisions. The skewness measure of $5.832044>1$ suggests that the distribution was irregular and highly skewed with a long tail to the right, meaning that most values were concentrated to the left of the mean with extreme values to the right. The kurtosis measure of $42.4513>3$ suggests a high probability of extreme values. Higher kurtosis means more variability due to a few extreme differences from the mean, rather than many modest differences from the mean. It is evident from the distribution analysis that the values of corporate accruals were not normally distributed and there was a high degree of variability. The statistical results suggest that corporate accruals have had a negative effect on the quality of financial reporting in Bangladesh. Indeed, corporate accruals can be attributed to the corporate manager mindset that is focused on achieving objectives (Hasan et al., 2014c).

Table 3. Descriptive statistics for accruals

\begin{tabular}{lccc}
\hline $\begin{array}{l}\text { Measurement } \\
\text { Scale }\end{array}$ & $\begin{array}{c}\text { Financial Statement } \\
\text { Accruals }\end{array}$ & $\begin{array}{c}\text { Estimated } \\
\text { Accruals }\end{array}$ & $\begin{array}{c}\text { Corporate } \\
\text { Accruals }\end{array}$ \\
\hline Max & 0.45121 & 0.4179 & 4.13481 \\
\hline Min & -0.30365 & -4.2679 & -0.36503 \\
\hline Average & 0.008798 & -0.34037 & 0.349171 \\
\hline SD & 0.124306 & 0.532604 & 0.521308 \\
\hline CV & 14.12973 & -1.56477 & 1.492989 \\
\hline Skewness & 0.52281 & -6.124 & 5.832044 \\
\hline Kurtosis & 1.916066 & 45.29173 & 42.4513 \\
\hline
\end{tabular}

SOURCE: EUROPEAN JOURNAL OF ECONOMICS AND MANAGEMENT, I(I), PP. I7-46.

\footnotetext{
${ }^{5}$ Dechow, P. M and Schrand, C. M. (2004). Earnings Quality. Monograph - Published by Research Foundation of CFA Institute, USA.
} 
Tables 4 and 5 show the statistical results relating to proxy 3 for users' perception about financial reporting quality. If we look at the existing financial reporting system (Table 4 ), the majority of the respondents (46.32\%) declare that the existing system is not effective. A mean score 2.75 indicates that the existing system is neither good nor bad. Several mean tests show a significant variation among respondents at the one percent level. This situation indicates the existing reporting system is not capable of protecting stakeholder rights. If we look at the perceived timeliness of accounting information (Table 4), the majority of the respondents (65\%) believe that companies act late when it comes to disclosing information and testing for the equality of several means shows that there is no significant variation among respondents about the timeliness of accounting information. In short, the reporting entities in Bangladesh do not produce quality financial reporting in terms of timeliness of accounting information. Regarding neutrality (Table 4), about $48 \%$ of respondents believe that the information included in corporate financial statements are either highly neutral or neutral. Conversely, about $40 \%$ respondents believe it is partially neutral or highly partial, while around $12 \%$ is undecided. Even some bankers, shareholders, academics, and tax officers think the information is not neutrally presented at all. A test for equality of several means shows that there is significant variation among respondents about the neutrality of accounting information. It could, therefore, be said that accounting information is not neutrally presented in annual reports. In terms of reliability, Table 5 reveals that $84.21 \%$ of respondents believe that information contained in annual reports is partly or not reliable while the rest believe it to be reliable. Chi-square results show that there is significant variation among respondents on the issue of reliability of accounting information. This situation indicates that the information provided in the annual reports is not reliable and confirms the general credibility crisis of secondary information in Bangladesh. If we look at the adequacy of information (Table 5), the majority of the respondents $(90.521 \%)$ believe that the information is not adequate. Adequate information is essential for making a judicious decision but in many quarters the information is strongly criticized for its inadequacy. Chi-square results show that there is no significant variation among respondents on this issue, making it clear that annual reports do not contain adequate information. If we look at auditor integrity and competency (Table 4), a percentile analysis of respondents' opinions on auditor integrity and competency reveals that $13.68 \%$ find auditors to be highly competent, $33.16 \%$ believe them to be of standard competence, $3.68 \%$ are neutral, $35.79 \%$ believe they are not competent, and $8.42 \%$ say that they are not competent at all. A mean score of 3.31 for auditor integrity is a fair indication that auditors do not properly maintain their professional integrity as the score is below four. A standard deviation of 1.22 and CV of 36.94 demonstrates inconsistency in the opinions of respondents. A test for equality of several means shows significant variation among respondents at the one percent level. Therefore, the perception about auditor integrity and competency is below the expected level. 
Table 4. Statistical analysis of users' perception

\begin{tabular}{|c|c|c|c|c|c|c|c|c|c|c|c|}
\hline \multirow{3}{*}{ Issues } & \multirow{3}{*}{$\begin{array}{l}f \\
\& \\
\%\end{array}$} & \multicolumn{9}{|c|}{ Descriptive Statistics } & \multirow{3}{*}{$\begin{array}{c}\text { F-value } \\
\text { (Several } \\
\text { means } \\
\text { test) }\end{array}$} \\
\hline & & \multicolumn{5}{|c|}{ Frequency } & \multirow{2}{*}{$\mathrm{N}$} & \multirow{2}{*}{ Mean } & \multirow{2}{*}{ SD } & \multirow{2}{*}{ CV } & \\
\hline & & 5 & 4 & 3 & 2 & 1 & & & & & \\
\hline \multirow{2}{*}{$\begin{array}{l}\text { Effectiveness of existing } \\
\text { financial reporting system } \\
\text { (Page:237) }\end{array}$} & $f$ & 5 & 62 & 19 & 88 & 16 & 190 & \multirow[b]{2}{*}{2.75} & \multirow[b]{2}{*}{1.08} & \multirow[b]{2}{*}{39.44} & \multirow[b]{2}{*}{$3.524^{\star \star}$} \\
\hline & $\%$ & 2.63 & 32.63 & 10 & 46.32 & 8.42 & 100 & & & & \\
\hline \multirow{2}{*}{$\begin{array}{l}\text { Neutrality of } \\
\text { accounting information } \\
\text { (Page: } 226)\end{array}$} & $f$ & 12 & 79 & 23 & 50 & 26 & 190 & \multirow[b]{2}{*}{3.01} & \multirow[b]{2}{*}{1.22} & \multirow[b]{2}{*}{40.57} & \multirow[b]{2}{*}{$8.499^{\star *}$} \\
\hline & $\%$ & 6.32 & 41.58 & 12.11 & 26.32 & 13.68 & 100 & & & & \\
\hline \multirow{2}{*}{$\begin{array}{l}\text { Perceived timeliness } \\
\text { (Page: 233) }\end{array}$} & $f$ & 16 & 61 & 26 & 65 & 22 & 190 & \multirow{2}{*}{2.92} & \multirow[b]{2}{*}{1.21} & \multirow{2}{*}{41.49} & \multirow{2}{*}{$3.765^{\star \star}$} \\
\hline & $\%$ & 8.42 & 32.11 & 13.68 & 34.21 & 11.58 & 100 & & & & \\
\hline
\end{tabular}

SOURCES: CORPORATE FINANCIAL REPORTING IN DEVELOPING COUNTRIES. EVIDENCE FROM BANGLADESH. GERMANY, OMNISCRIPTUM GMBH \& CO. KG.

\section{Table 5. Statistical analysis of users' perception}

\begin{tabular}{lccccccc}
\hline Issues & $\mathbf{f ~ \& ~ \% ~}$ & Fully & Partly & Not at All & Total & $\chi^{2}$ \\
\hline \multirow{2}{*}{ Reliability of accounting information } & $\mathrm{F}$ & 30 & 114 & 46 & 190 & \multirow{2}{*}{$16.058^{\star *}$} \\
\cline { 2 - 7 } & $\%$ & 15.79 & 60 & 24.21 & 100 & \\
\hline \multirow{2}{*}{ Adequacy of accounting information } & $\mathrm{F}$ & 18 & 110 & 62 & 190 & \multirow{4}{*}{$4.612^{\text {** }}$} \\
\cline { 2 - 6 } & $\%$ & 9.473 & 57.89 & 32.631 & 100 & \\
\hline
\end{tabular}

SOURCE: ICAN JOURNAL OF ACCOUNTING \& FINANCE, I(4), PP. 64-65.

\section{Conclusions}

We conclude that the quality of corporate financial reporting of listed companies in Bangladesh is far below the expected level. We consider three proxies in all, including the level of disclosures (proxy 1 ) and corporate accruals (proxy 2) as quantitative measures along with users' perception (proxy 3 ) as a qualitative measure, in order to cover three important aspects of financial reporting. We reveal a low disclosure index (67\%), high corporate accruals (35\%), and respondents' negative perceptions (about the effectiveness of existing financial reporting, timeliness, neutrality, reliability, adequacy, and auditor integrity) this indicating that financial reporting quality in Bangladesh is poor or non-existent. Proxy 1 and proxy 3 represent new contributions to the procedure for assessing the quality of financial reports. This study will help stakeholders such as regulators, management, auditors, boards of directors, financial analysts, researchers, academics, and so on, to improve the current scenario. The limitation of this study concerns the use of a range information relating to disclosure, corporate accruals and users' perception about financial reporting. A preferable approach would be to conduct a reallife study on corporate financial reporting quality using these three proxies. 


\section{References}

Barth, M., Beaver, W. and Landsman, W. (2001). The relevance of the value relevance literature for financial accounting standard setting: another view, Journal of Accounting and Economics, 31, pp. 77-104.

Barth, M., Landsman, W. and Lang, M. (2008). International accounting standards and accounting quality, Journal of Accounting Research, 46(3), pp. 467-498.

Beest,V. F., Braam, G. and Boelens, S. (2009). Quality of financial reporting: measuring qualitative characteristics, Nijmegen Center for Economics, NICE Working Paper 09, p. 108.

Biddle, G.C., Hilary, G. and Verdi, R.S. (2009). How does financial reporting quality relate to investment efficiency?, Journal of Accounting and Economics, 48(2-3), pp.112-131.

Botosan, C. (2004). Discussion of a framework for the analysis of risk communication, The International Journal of Accounting, 39, pp. 289-295.

Beretta, S. and Bozzolan, S. (2004). A framework for the analysis of firm risk communication, The International Journal of Accounting, 39, pp. 265-288.

Chen, F., Hope, O.K., Li, Q. and Wang X. (2011). Financial reporting quality and investment efficiency of private firms in emerging markets, The Accounting Review, 86(4), pp. 1255-1288.

Choi, B., Collins, D.W. and Johnson, W.B. (1997). Valuation implications of reliability differences: The case of nonpension postretirement obligations, The Accounting Review,72(3), pp. 351-383.

Cohen, J., Krishnamorthy, G. and Wright, A. (2004). The corporate governance mosaic and financial reporting quality, Journal of Accounting Literature, 23, pp. 87-152.

Daske, H. and Gebhardt, G. (2006). International financial reporting standards and experts' perceptions of disclosure quality, Abacus, 42(3-4), pp. 461-498.

Dechow, P., Solan, R.G. and Sweeny, A.P. (1995). Detecting earnings management, The Accounting Review, 70(2), pp. 193-225.

Dechow, P. and Dichev, I. (2002). The quality of accruals and earnings: The role of accrual estimation errors, The Accounting Review, 77(Supplement), pp. 35-59.

Francis, J., La Fond, R., Olsson, P. and Schipper, K. (2005). The market pricing of accruals quality, Journal of Accounting and Economics, 39(2), pp. 295-327.

Gaeremynck, A. and Willekens, M. (2003). The endogenous relationship between audit-report type and business termination: Evidence on private firms in a non- litigious environment, Accounting and Business Research, 33(1), pp. 65-79.

Hasan, M.S., Omar, N. and Hossain, S.Z. (2015). Corporate attributes and corporate accruals, AESTIMATIO, the IEB International Journal of Finance, 12 (forthcoming).

Hasan, M.S., Abdul Rahman, R. and Hossain, S.Z. (2014a). Monitoring family performance: family ownership and corporate governance structure in Bangladesh, Procedia Social and Behavioral Sciences, 145, pp. 103-109.

Hasan, M.S., Abdul Rahman, R. and Hossain, S.Z. (2014b). Corporate accruals practices of listed companies in Bangladesh, European Journal of Economics and Management, 1(1), pp. 17-46. 
Hasan, M.S., Hossain, S.Z. and Abdul Rahman, R. (2014c). Corporate governance and corporate accruals: the situation in Bangladesh, AESTIMATIO, the IEB International Journal of Finance, 9, pp. 90-111. $\square$

Hasan, M.S., Abdullah, S.N. and Hossain, S.Z. (2014d). Qualitative characteristics of financial reporting: An evaluation of users' perception in Bangladesh, The Pakistan Accountant, 50(1), pp. 23-31.

Hasan, M.S., Hossain, S.Z. and Swieringa, R.J. (2013a). Corporate governance and financial Disclosures, Research Journal of Finance and Accounting, 4(1), pp. 109-119.

Hasan, M.S. and Hossain, S.Z. (2013b). Corporate attributes and financial disclosures: Bangladesh experience, ICAN Journal of Accounting \& Finance, 2(1), pp. 31-43.

Hasan, M.S. (2012a). Corporate financial reporting in developing countries, OmniScriptum GmbH \& Co. KG, Germany.

Hasan, M.S. and Hossain, S.Z. (2012b). Anatomy of disclosure index in Bangladesh, ICAN Journal of Accounting \& Finance, 1(4), pp. 53-72.

Hasan, M.S. and Hossain, S.Z. (2012c). Measurement and analysis of disclosure level: Bangladesh perspective, The Pakistan Accountant, 48(4), pp. 15-19.

Hirst, D., Hopkins, P. and Wahlen, J. (2004). Fair values, income measurement, and bank analysts' risk and valuation judgments, The Accounting Review, 79(2), pp. 453-472.

Healy, P. and Wahlen, J. (1999). A review of the earnings management literature and its implications for standard settings, Accounting Horizons, 13(4), pp. 365-383.

Kothari, S.P., Leone, A.J. and Wasley, C.E. (2005). Performance matched corporate accrual Measures, Journal of Accounting and Economics, 39, pp. 163-197.

Leuz, C. (2003). IAS Versus U.S. GAAP: Information asymmetry-Based on evidence from Germany's new market, Journal of Accounting Research, 41(9), pp. 445-472.

Leuz, C., and Wysocki, D.P. (2008). Economic consequences of financial reporting and disclosure regulation: A review and suggestions for future research. Available at: http://papers.ssrn.com/sol3/papers.cfm? abstract_id $=1105398$

McNichols, M. (2002). Discussion of the quality of accruals and earnings: The role of accrual estimation errors, The Accounting Review, 77 (Supplement), pp. 61-69.

McNichols, M.F. and Stubben, S.R. (2008). Does earnings management affect firms' investment decisions?, The Accounting Review, 83, pp. 1571-1603.

Nichols, D. and Wahlen, J. (2004). How do earnings numbers relate to stock returns? A review of classic accounting research with updated evidence, Accounting Horizons, 18(4), pp. 263-286.

Schipper, K. and Vincent, L. (2003). Earnings quality, Accounting Horizons, 17(Supplement), pp. 97-110.

Stubben, S.R. (2010). Corporate revenues as a measure of earnings management, The Accounting Review, 85(2), pp. 695-717.

Tang, Q. (2008). Financial reporting quality in developed and emerging markets, Tenth Annual International Conference on Accounting and Business, Shanghai, June 6-8. 
